\title{
PERAN MEDIASI KINERJA PROSES INTERNAL ATAS HUBUNGAN STRATEGI INOVASI DENGAN KINERJA KEUANGAN
}

\author{
Hariyati \\ hariyati@unesa.ac.id \\ Universitas Negeri Surabaya \\ Bambang Tjahjadi \\ Universitas Airlangga Surabaya
}

\begin{abstract}
This research examines the relation between innovation strategy and company's financial performance through mediation between internal process performance. The hypothesis in this research is that the innovation strategy affects the financial performance which is mediated by internal process performance. This research is a quantitative research in the explanatory level. The population of this research is all of the manufacturer companies in East Java. There are 398 companies. The data is collected through questionnaires. There are 135 questionnaires or response rate for $34 \%$. The analysis unit is business unit. The research respondent is the manager of business unit in Manufacturing Company in East Java. The research result shows that the internal process performance mediates partially the relation between innovation strategy and financial performance.The results of this study have important implications to management of manufacturing companies. They must be aware of product as well as process inovation strategy in order to achieve performance. Furthermore, management must concern in the development of management accounting information systems because it plays strategic role in making good decisions and improving internal business performace. This study also expand contextual variables in contingency theory.
\end{abstract}

Key words: innovation strategy, mediation, financial performance, internal process performance.

\begin{abstract}
ABSTRAK
Penelitian ini menguji hubungan antara strategi inovasi dengan kinerja keuangan yang dimediasi oleh kinerja proses internal. Hipotesis dalam penelitian ini adalah strategi inoveasi berpengruh terhadap kinerja keuangan yang dimediasi oleh kinerja proses internal. Penelitian ini merupakan penelitian kuantitatif pada tingkat eksplanasi.Populasi dalam penelitian ini adalah semua perusahaan manufaktur yang berlokasi di Jawa Timur. Terdapat 398 perusahaan. Data dikumpulkan melalui kuesioner. Terdapat 135 kuesioner atau 34\% yang kembali dan diolah lebih jauh atau 34\%. Unit analis dalam penelitian ini adalah unit bisnis. Responden dalam penelitian ini adalah manajer unit bisnis pada perusahaan manufaktur di Jawa Timur. Hasil penelitian menunjukkan bahwa kinerja proses internal memediasi hubungan antara strategi inovasi dengan kinerja keuangan. Hasil penelitian ini juga memiliki implikasi penting untuk manajemen perusahaan manufaktur. Mereka harus menyadari pentingnya inovasi produk dan proses dalam strategi inovasi untuk mencapai kinerja. Manajemen harus memperhatikan dalam pengembangan proses internalnya, karena memainkan peran strategis dalam membuat keputusan yang baik dan meningkatkan performace bisnis internal. Penelitian ini juga memperluas variabel kontekstual dalam teori kontingensi.
\end{abstract}

Kata kunci: strategi inovasi, mediasi, kinerja keuangan, kinerja proses internal.

\section{PENDAHULUAN}

Dengan hadirnya Masyarakat Ekonomi Asia ini, semua Entitas yang berorientasi ke laba di Indonesia memiliki peluang untuk memanfaatkan keunggulan skala ekonomi dalam negeri sebagai basis memperoleh keuntungan. Agar memperoleh keuntungan diatas rata-rata industri maka entitas dituntut untuk menghasilkan kinerja yang baik, baik kinerja keuangan maupun non 
keuangan. Pencapaian kinerja non keuangan yang baik akan berdampak pada kinerja keuangan harus dapat diukur dengan jelas. Diperlukan pengukuran kinerja yang sesuai sebagai tolok ukur perencanaan, pengendalian dan evaluasi.

Pengukuran kinerja dapat ditinjau dari pengukuran yang bersifat tunggal dan pengukuran yang bersifat komprehensif. Pengukuran kinerja yang komprehensif meliputi pengukuran kinerja dari berbagai aspek (Cardinaels dan Van Veen-Dirks, 2010). Pengukuran kinerja dari aspek tunggal tidak dapat menginformasikan aspek yang komprehensif (Bhargava et al., 1994). Pengukuran kinerja harus menginformasikan pengukuran dari semua aspek sehingga menjadi pengukuran kinerja yang komprehensif (Banker et al., 2004., Bhargava et al., 1994; Venkatraman dan Ramunajam, 1986). Merancang pengukuran kinerja entitas dibutuhkan model yang sesuai. Pengukuran kinerja dengan model yang sesuai akan mampu menggambarkan kinerja keseluruhan dari entitas.

Balanced scorecard (BSC) oleh Kaplan dan Norton, (2001) merupakan salah satu pengukuran kinerja yang bersifat multidimensional. BSC meliputi kinerja non keuangan dan keuangan yang terdiri dari 4 (empat) perspektif (Burney dan Swanson, 2010). Perspektif tersebut adalah perspektif keuangan yang dihasilkan dari 3 (tiga) perspektif lainnya yaitu perspektif pelanggan yang menunjukkan kinerja pelanggan, perspektif internal proses bisnis yang menunjukkan kinerja proses internal, dan perspektif pembelajaran dan pertumbuhan. Hal yang sama juga telah diungkapkan oleh Banker et al., 2004 yang mengatakan BSC merupakan pengukuran yang komprehensif, karena mengukur kinerja keuangan dan non keuangan.

Kinerja keuangan merupakan proses akhir dari aktivitas organisasi yang berorientasi ke laba. Kinerja keuangan berfokus pada pertumbuhan pendapatan, pengurangan atau penghematan biaya dan peningkatan penggunaan aset. Kinerja keuangan yang baik tergantung pada proses kinerja non keuangan, seperti kinerja proses internal. Kinerja proses internal merupakan salah satu proses pengendalian manajemen. Menurut Scheer (2006), Proses pengendalian ini meliputi pon poin: (1) Evaluasi, analisis dan perbaikan terus menerus atas alur kerja bisnis baik secara otomatis maupun manual, (2) Peta proses realitas dengan cara berorientasi pada isu tugas dan tugas yang telah dilakukan, (3) Hasil dari proses pengendalian adalah transparansi proses, dalam hal struktural dan untuk tujuan evaluasi, (4) Hasil dari proses internal digunakan sebagai basepoint untuk optimasi proses. Kinerja proses ini internal meliputi operations management process, customer management process, innovations process dan regulatory dan social process.

Untuk mencapai kinerja yang baik (non keuangan maupun keuangan), maka entitas harus mempunyai Competitive advantage, sehingga dapat bersaing dipasar global. Competitive advantage dapat dicapai dengan memiliki strategi bersaing yang tepat. Hambrick (1981) menyatakan bahwa strategi entitas merupakan pola keputusan yang berhubungan dengan pencapaian kinerja. Kinerja entitas yang bersifat multidimensial harus dicapai agar entitas dapat mencapai kinerja diatas rata rata industri. Terdapat kesenjangan teori terkait dengan strategi untuk mencapai competitive advantage atas kinerja diatas rata rata industri. Teori Organisasi Industrial (Industrial Organization) yang menekankan bahwa untuk mencapai kinerja organisasi atau perusahaan atau entitas dengan kinerja diatas rata-rata industri harus memperhatikan dan mempelajari faktor-faktor dan lingkungan eksternal (Porter, 2008). Menurut Resource Based Theory, menekankan untuk mencapai kinerja organisasi atau perusahaan dengan kinerja diatas rata-rata industri sangat ditentukan oleh karakteristik dan faktor-faktor internal perusahaan (Barney et al., 2001). Untuk menutupi kesenjangan kedua teori tersebut 
maka, dalam penelitian ini digunakan Contingency Theory. Alasan menggunakan Contingency Theory karena tidak ada konsep atau desain organisasi yang akan bisa diterapkan secara universal di mana saja atau dalam kondisi apa saja dan secara efektif (Otley, 1980). Suatu desain organisasi hanya sesuai atau cocok (fit) untuk suatu konteks atau kondisi tertentu saja. Implementasi dalam Resource Based Theory dan Industrial Organizationtheory sangat tergantung pada variabel-variabel kontijensi seperti yang dijelaskan dalam Contingency Theory (Cadez dan Guilding, 2008). Penggunaan Contingency Theory inilah mendorong peneliti mengidentifikasi kondisi yang sesuai untuk desain organisasi tertentu dan mengembangkan teori yang mendukungnya. Mendasarkan pada konsep teori tersebut maka strategi inovasi berdampak pada kinerja keuangan jika terdapat kinerja proses internal yang baik.

Diera MEA, inovasi memainkan peran utama dalam menembus pasar baru, mempertahankan pangsa pasar yang sudah ada dan meningkatkan keunggulan kompetitif perusahaan. Inovasi merupakan elemen penting dari strategi bisnis perusahaan, karena inovasi telah menjadi kontributor penting bagi pemenangan persaingan. Inovasi telah menjadi fokus utama dari penelitian akademik dan industri secara intensif dalam rangka mengatasi berbagai problematika bisnis yang tengah dihadapi oleh perusahaan untuk mencapai keunggulan kompetitif yang berkelanjutan dalam persaingan global (Hitt et al., 2001; Kuratko et al., 2005). Tujuan dari inovasi tidak hanya untuk mengurangi biaya semata, akan tetapi juga untuk peningkatan kualitas produk dan pelayanan, merancang produk yang lebih baik, daur hidup produk yang lebih panjang, dan merespon kebutuhan dan tuntutan pelanggan. Disamping itu, inovasi dilakukan untuk mengembangkan produk dan pelayanan baru, model organisasi yang baru dan teknik pemasaran baru. Beberapa hasil penelitian mengemukakan bahwa perusaha an jaman sekarang harus lebih inovatif agar dapat bersaing lebih baik di pasar mereka (Evangelista et al., 1998). Persaingan global memaksa perusahaan untuk melakukan inovasi dengan mengurangi biaya produksi dan meningkatkan kemampuan teknologi serta melakukan inovasi produk. Mengingat tujuan tersebut, perusahaan perlu merekayasa struktur organisasi dan pekerjaan mereka, meningkatkan kompetensi inti, mengembangkan struktur baru untuk merespon kondisi pasar baru dan permintaan pelanggan, serta menetapkan pasar yang berbeda, meningkatkan jalinan kolaborasi dengan perusahaan lain, dan menanamkan investasi untuk inovasi (Ulusoy et al.,2001). Dibrell et al., (2008) menekankan bahwa inovasi dalam berstrategi bervariasi dalam kompleksitas dari perubahan kecil yang meliputi produk, proses, atau jasa yang ada terobosan produk, dan proses atau jasa yang memperkenalkan fitur pertama kali atau luar biasa prestasinya. Konsep inovasi dalam berstrategi didefinisikan sebagai struktur baru atau proses manajemen, kebijakan, rencana atau program baru, proses produksi baru, atau produk atau layanan baru yang diproduksi di suatu perusahaan (LopezNicolas dan Merono-Cerdan, 2011). Oleh karena itu Strategi inovasi merupakan hal yang sangat penting.

Strateggi inovasi mengacu pada seluruh rangkaian praktik inovatif yang melibatkan analisis mekanisme dalam bersaing, seperti membuat suatu visi yang inovatif, harmonisasi strategi bisnis, memperluas strategi untuk semua tingkatan organisasi, kecenderungan pasar, teknologi dan tindakan pesaing (Sanchez et al., 2011). Konsep ini menjelaskan proses terdiri dari banyak bagian, tidak ada definisi umum dan jelas di mana semua para ahli sepakat tentang isi dan komponen dari konsep. Sukses bisnis di era MEA ditentukan oleh inovasi. Inovasi diartikan sebagai proses di dalam organisasi untuk memanfaatkan ketrampilan dan sumber daya untuk mengembangkan produk dan atau jasa baru atau untuk membangun sistem produksi dan operasional baru sehingga mampu menjawab kebutuhan 
pelanggan (Jones, 2004). Pengaruh inovasi terhadap indikator kinerja perusahaan (kepuasan pelanggan, produktivitas dan daya saing teknologi) telah dibuktikan oleh Terziovski (2002). Strategi berkelanjutan dari bawah - atas (bottom-up) lebih disukai untuk peningkatan kepuasan pelanggan dan produktivitas (Terziovski, 2002).

Sementara strategi top-down lebih cocok untuk peningkatan daya saing teknologi. Hasil penelitian Terziovski, lebih lanjut menunjukkan bahwa strategi terintegrasi tidak terlalu besar pengaruhnya terhadap kinerja. Hal ini disebabkan karena perusahaan pada umumnya belum mencapai tahap integrasi sistem dan kemampuan beroperasi dalam jaringan (networking). Strategi incremental lebih tepat digunakan sebagai pendorong bagi inovasi yang berkelanjutan, sedangkan strategi radikal lebih tepat digunakan untuk melakukan inovasi yang menghasilkan perubahan produk dan proses secara cepat. Implementasi strategi inovasi juga ditentukan oleh faktor-faktor penentu. Penentu utama dalam strategi inovasi, struktur organisasi, budaya inovasi, kemampuan teknologi dan hubungan dengan pelanggan dan pemasok (Igartua et al., 2010; Sanchez et al., 2011; Terziovski, 2010).

Dalam menghadapi ketidakpastian lingkungan dan persaingan yang semakin tajam maka, beberapa perusahaan mencoba untuk menerapkan berbagai strategi yang berbeda dengan para pesaing mereka, terutama dalam memantapkan posisi mereka sebagai yang paling inovatif, sebagai produsen yang paling hemat biaya, dan sebagai perusahaan yang paling responsif terhadap perubahan pasar. Perusahaan yang memposisikan diri sebagai salah satu yang paling inovatif di pasar, akan berjuang untuk mengetahui kebutuhan pelanggan yang belum terpenuhi dengan mengembangkan produk dan pelayanan baru guna memenuhi kebutuhan ini (Bisbe dan Otley, 2004). Beberapa perusahaan ternyata lebih unggul dari yang lain dalam mencapai tujuan ini karena mempertimbangkan berbagai faktor internal dan eksternal yang mereka hadapi.
Dalam menghadapi MEA semua entitas harus mempunyai competitive advantage agar dapat bersaing dipasar Asia. Di Indonesia, isu tentang inovasi produk dan proses diberbagai bidang usaha manufaktur menjadi isu yang menarik. Hal ini terjadi karena siklus hidup produk yang semakin pendek. Proses produksi dengan cost yang rendah dengan tetap mengedepankan mutu yang baik juga menjadi hal yang menarik perhatian. Di Indonesia, khususnya di Jawa Timur terdapat kurang lebih 1266 entitas (Disperindag, 2016) yang tergolong pada entitas manufaktur besar dan menengah. Tingkat pertumbuhan entitas manufaktur berfluktuasi sejak tahun 2012.

Berdasarkan data Dinas Perindustrian dan Perdagangan Jawa Timur, entitas manufaktur di Jawa Timur pada tahun 2012 menduduki peringkat ketiga sesudah DKI Jakarta dan Kalimantan Timur dalam hal kinerja ekspornya yaitu memberikan sumbangan sebesar 10,04\% atas kinerja ekspor di Indonesia. Jawa Timur memberikan sumbangan PDB terbesar yaitu sebesar 20,85\% (Majalah Industri, 2016). Menghadapi era globalisasi, entitas manufaktur di Jawa Timur harus mempunyai keunggulan bersaing. Mencapai keunggulan bersaing dengan menerapkan strategi yang tepat yaitu strategi inovasi yang berkelanjutan melalui inovasi produk dan inovasi proses dengan memperhatikan kinerja proses internal.

Tujuan dan motivasi dari penelitian ini adalah (1) mengeksplor implementasi RBT dengan memasukkan variabel-variabel kontijensi, (2) menguji pengaruh strategi inovasi terhadap kinerja keuangan yang dimediasi oleh kinerja proses internal, (3) membuktikan bahwa strategi inovasi suatu entitas manufaktur dapat berfungsi sebagai petunjuk dan pegangan bagi eksekutif pelaksana dalam mencapai kinerja keuangan yang baik melalui kinerja proses internal yang baik. Berdasarkan hal tersebut diatas maka terdapat beberapa permasalahan yang perlu diteliti adalah bagaimana entitas dapat mencapai kinerja keuangan yang optimal dengan implementasi strategi inovasi me- 
lalui variabel-variabel konstektual dalam pendekatan kontijensi, oleh karena itu, topik dari penelitian ini adalah bagaimana pemodelan strategi inovasi dengan kinerja keuangan yang dimediasi oleh Kinerja proses internal.

\section{TINJAUAN TEORETIS Teori Kontijensi}

Pendekatan kontijensi pada akuntansi manajemen didasarkan pada premis bahwa tidak ada sistem akuntansi secara universal selalu tepat untuk dapat diterapkan pada setiap entitas, tetapi hal ini tergantung pada faktor kondisi atau situasi yang ada dalam entitas. Beberapa peneliti dalam bidang akuntansi manajemen melakukan pengujian untuk melihat hubungan variabel-variabel kontekstual seperti ketidakpastian lingkungan, ketidak pastian tugas, struktur dan kultur entitasional, ketidakpastian strategi dengan desain sistem akuntansi manajemen.

Suatu desain entitas hanya sesuai atau cocok (fit) untuk suatu konteks atau kondisi tertentu saja. Penggunaan pendekatan kontijensi mendorong peneliti untuk mengidentifikasi kondisi yang sesuai untuk desain entitas tertentu dan mengembangkan teori yang mendukungnya (Riyanto, 1999). Teori kontijensi mengidentifikasi bentuk-bentuk optimal pengendalian entitas di bawah kondisi operasi yang berbeda dan menjelaskan bagaimana prosedur operasi pengendalian entitas tersebut. Otley (1980) menyatakan bahwa pendekatan kontijensi dapat menjelaskan mengapa sistem akuntansi dapat berbeda dari kondisi yang satu ke kondisi yang lain. Berdasarkan temuannya disimpulkan bahwa ada tiga konsep yang mempengaruhi efektivitas sistem akuntansi yaitu (1) teknologi, (2) struktur entitas, dan (3) lingkungan.

\section{Resource Based Theory}

Untuk mencapai competitive advantage diperlukan peran dari factor internal sebuah entitas (Brahmana, 2007). Dalam Resources Based Theory menyatakan bahwa faktor internal lebih penting dari eksternal (indus- tri) dalam entitas untuk mencapai keunggulan bersaing. Resources Based Theory merupakan pandangan dengan fokus sumber daya dan kapabilitas yang merupakan asas fundamental yang menentukan kesejahteraan masyarakat. Modal suatu entitas berkaitan dengan modal manusia dan modal phisik, yang menentukan proses pemberdayaan kearah penciptaan daya saing entitas dan pada akhirnya pada peningkatan kesejahteraan masyarakat. Kemampuan pelaku pemberdayaan ditentukan dari akumulasi berbagai macam modal yang ada, yang pada hakikatnya dihubungkan dengan pandangan resource base. Pendapat Teece et al., (1997) menyatakan bahwa keunggulan daya saing tergantung pada sumber daya yang dimiliki entitas. Gagasan tersebut berasal dari stratejik manajemen, yang dihubungkan dengan pandangan Resources Based Theory.

Hasil penelitian Barney et al., (2001) menyatakan bahwa, Resources Based Theory memandang entitas sebagai kumpulan sumber daya dan kemampuan yang dimiliki entitas. Perbedaan sumber daya dan kemampuan entitas dengan entitas pesaing akan memberikan keuntungan kompetitif bagi entitas. Asumsi Resources Based Theory yaitu bagaimana entitas dapat bersaing dengan entitas lain untuk mendapatkan keunggulan kompetitif dalam mengelola sumber daya yang dimilikinya sesuai dengan kemampuan entitas. Menurut Resources Based Theory agar memberikan hasil yang optimal, maka sumber daya harus memenuhi kriteria sebagai berikut: (1) valuable artinya sumber daya akan menjadi berharga jika dapat memberikan nilai strategis pada entitas, (2) langka artinya sumber daya harus mempunyai keunikan dalam arti yang sulit untuk ditemukan diantara para pesaing dan menjadi potensi entitas, (3) imperfect imitability artinyasumber daya dapat menjadi sumber keunggulan kompetitif yang berkelanjutan, hanya jika entitas yang tidak memegang sumber daya ini tidak bisa mendapatkan mereka atau tidak dapat meniru sumber daya tersebut, (4) 
non-substitution artinya sumber daya tidak dapat disubstitusikan oleh sumber daya alternatif lainnya.

\section{Strategi Inovasi}

Adanya pemberlakuan MEA maka, inovasi memainkan peran utama dalam kegiatan ekonomi. Entitas yang melakukan inovasi diharapkan dapat menembus pasar baru, mempertahankan pangsa pasar yang sudah ada dan meningkatkan keunggulan kompetitif. Inovasi merupakan elemen penting dari strategi bisnis entitas. Inovasi telah menjadi kontributor penting bagi pemenangan persaingan. Inovasi telah menjadi fokus utama dari penelitian akademik dan industri secara intensif dalam rangka mengatasi berbagai problematika bisnis yang tengah dihadapi oleh entitas. Inovasi dalam implementasi strategi berperan mencapai keunggulan kompetitif yang berkelanjutan dalam persaingan global (Hitt et al., 2001; Kuratko et al., 2005). Tujuan dari inovasi tidak hanya untuk mengurangi biaya, tetapi juga untuk peningkatan kualitas produk dan pelayanan, merancang produk yang lebih baik, daur hidup produk yang lebih panjang, dan merespon kebutuhan dan tuntutan pelanggan. Disamping itu, inovasi dilakukan untuk mengembangkan produk dan pelayanan baru, model entitas yang baru dan teknik pemasaran baru.

Entitas harus inovatif agar dapat bersaing dengan baik di pasar global (Evangelista et al., 1998). Persaingan global memaksa entitas untuk melakukan inovasi dengan mengurangi biaya produksi dan meningkatkan kemampuan teknologi serta melakukan inovasi produk. Entitas perlu merekayasa struktur entitas dan pekerjaan mereka, meningkatkan kompetensi inti, mengembangkan struktur baru untuk merespon kondisi pasar baru dan permintaan pelanggan, serta menetapkan pasar yang berbeda, meningkatkan jalinan kolaborasi dengan entitas lain, dan menanamkan investasi untuk inovasi (Ulusoy et al., 2001). Strategi Inovasi adalah panduan yang membuat perusahaan berpikir tentang mengapa mereka berinovasi sebelum mencoba untuk membuat inovasi. Strategi Inovasi ini berdampak pada kinerja keuangan dan pertumbuhan daerah mengenai barang atau jasa baru; itu adalah kriteria keseluruhan menyediakan satu set filter melalui mana pengertian tentang peran strategis dan produk atau jasa baru harus lulus, sehingga mendefinisikan misi strategis produk atau jasa baru. Menurut Lendel dan Varmus (2011), Strategi Inovasi adalah menentukan strategi membentuk pendekatan ke tujuan, metode dan cara-cara untuk meningkatkan dan memperbaiki potensi inovatif perusahaan. Strategi Inovasi memungkinkan manajemen puncak untuk mengikuti kegiatan pesaing mereka, untuk mencapai informasi pasar pelanggan, untuk menggunakan sumber daya perusahaan secara efektif dan untuk membuat investasi yang efisien dalam penelitian dan pengembangan (Oke et al., 2012).

Adanya inovasi menentukan kesuksesan entitas (Bontis et al., 2002. Hamel, 1999). Inovasi diartikan sebagai proses di dalam entitas untuk memanfaatkan ketrampilan dan sumber daya untuk mengembangkan produk dan atau jasa baru atau untuk membangun sistem produksi dan operasional baru sehingga mampu menjawab kebutuhan pelanggan (Jones, 2004). Pengaruh inovasi terhadap kinerja entitas telah dibuktikan oleh Terziovski (2002). Strategi berkelanjutan dari bawah-atas (bottom-up) lebih disukai untuk peningkatan kepuasan pelanggan dan produktivitas (Terziovski, 2002). Sementara strategi top-down lebih cocok untuk peningkatan daya saing teknologi. Hasil penelitian Terziovski (2010), lebih lanjut menunjukkan bahwa strategi radikal tepat digunakan untuk melakukan inovasi yang menghasilkan perubahan produk dan proses secara cepat. Strategi Inovasi merupakan suatu proses yang memiliki komponen yang berbeda dan, pada saat yang sama, membutuhkan pengelolaan komponen yang berbeda secara keseluruhan sehingga terjadi sebuah keunikan dalam 
produk dan proses (Igartua et al., 2010). Ketika literatur mengenai praktik SIM diperiksa, terlihat bahwa penentu utama dalam strategi inovasi, struktur organisasi, budaya inovasi, kemampuan teknologi dan hubungan dengan pelanggan dan pemasok (Igartua et al., 2010; Sanchez et al., 2011; Terziovski, 2009, 2010).

Dalam menghadapi ketidakpastian lingkungan dan persaingan yang semakin tajam maka, beberapa entitas mencoba untuk menerapkan berbagai strategi yang berbeda dengan para pesaing mereka, terutama dalam memantapkan posisi mereka sebagai yang paling inovatif, sebagai produsen yang paling hemat biaya, dan sebagai entitas yang paling responsif terhadap perubahan pasar. Entitas yang memposisikan diri sebagai salah satu yang paling inovatif di pasar, akan berjuang untuk mengetahui kebutuhan pelanggan yang belum terpenuhi dengan mengembangkan produk dan pelayanan baru guna memenuhi kebutuhan ini. Beberapa entitas ternyata lebih unggul dari yang lain dalam mencapai tujuan ini karena mempertimbangkan berbagai faktor internal dan eksternal yang mereka hadapi.

\section{Kinerja Keuangan}

Kinerja perusahaan menjelaskan tentang kondisi keuangan suatu perusahaan. Dalam Balanced scorecard, perspektif keuangan merupakan sasaran akhir untuk profit maximizing companies. Ukuran-ukuran kinerja keuangan mengindikasikan apakah strategi entitas, termasuk implementasi dan pelaksanaannya, memberikan kontribusi pada perbaikan bottom-line. Kinerja keuangan entitas diperbaiki melalui dua pendekatan dasar yaitu revenue growth dan productivity. Entitas dapat menghasilkan profitable revenue dengan cara memperdalam hubungan dengan pelanggan yang ada, menjual produk, menjual pada pelanggan dalam segmen secara keseluruhan. Perbaikan produktivitas dapat terjadi dalam dua cara, yaitu entitas mengurangi biaya dengan menurunkan direct and indirect expenses atau dengan menggunakan financial and physical asset dengan lebih efisien, mengurangi working and fixed capital yang dibutuhkan untuk mendukung sebuah level bisnis yang diberikan. Keterkaitan strategi dalam perspektif keuangan muncul ketika entitas memilih sebuah keseimbangan antara pertumbuhan dan produktivitas. Variabel kinerja keuangan ini meliputi 3 (tiga) indikator yaitu: pertumbuhan pendapatan, pengurangan atau penghematan biaya dan peningkatan penggunaan asset serta peningkatan nilai pelanggan.

\section{Kinerja Proses Internal}

Perusahaan atau Organisasi mengelola proses internal dan pengembangan manusia, informasi, serta modal organisasi untuk mengirimkan proposisi nilai yang berbeda dari strategi. Kaplan dan Norton (2001), mengelompokkan proses internal organisasi ke dalam empat kelompok sebagai berikut. (1) Operations management processes adalah proses dasar, proses sehari-hari di mana perusahaan menghasilkan barang dan jasa dalam mengirimkannya ke pelanggan. Operations management processes dari perusahaan manufaktur terdiri dari: perolehan bahan mentah dari pemasok, mengkonversi bahan mentah menjadi barang jadi, mendistribusikan barang jadi ke pelanggan, dan mengelola risiko, (2) Customer management processess mem- perluas dan memperdalam hubungan dengan pelanggan yang ditargetkan. Terdapat empat rangkaian proses manajemen pelanggan, yaitu: memilih pelanggan yang ditargetkan, memperoleh pelanggan yang ditargetkan, mempertahankan pelanggan, dan menumbuhkan bisnis dengan pelanggan, (3) Innovation processes mengembangkan produk, proses, dan jasa baru yang memungkinkan perusahaan untuk menekan pasar dan segmen pelanggan baru. Mengelola inovasi meliputi empat rangkaian proses, yaitu: mengidentifikasi peluang untuk barang dan jasa baru, mengelola penelitian dan pengembangan portofolio, merancang dan mengembangkan barang dan jasa baru, serta membawa barang dan jasa baru ke 
pasar, (4) Regulatory and social processes membantu organisasi secara terus menerus mendapat hak untuk beroperasi dalam komunitas dan negara di mana barang diproduksi dan dijual. Perusahaan mengelola dan melaporkan regulatory and social performance sepanjang sejumlah dimensi penting, yaitu: lingkungan, keamanan dan kesehatan, praktik karyawan, dan investasi komunitas.

\section{Model Penelitian}

Berdasarkan rerangka teoritis dikembangkan model penelitian seperti disajikan pada Gambar 1 dibawah ini. Model penelitian tersebut menggambarkan bahwa strategi inovasi berpengaruh terhadap kinerja keuangan yang dimediasi oleh kinerja proses internal.

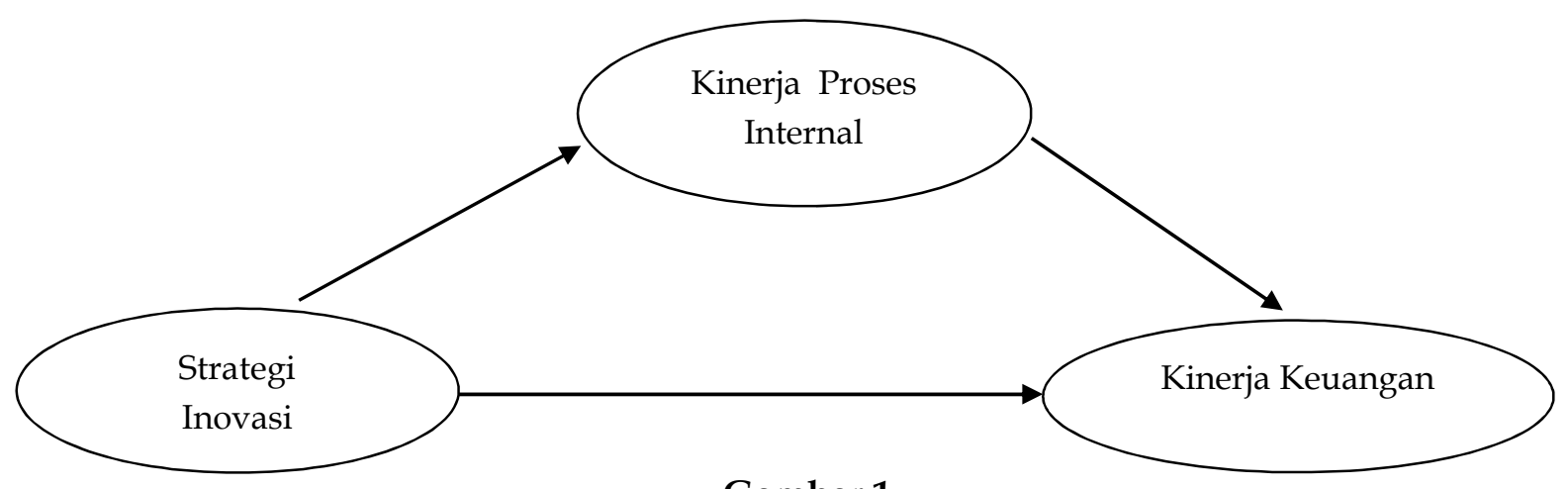

Gambar 1

Model Penelitian

\section{METODE PENELITIAN}

\section{Rancangan Penelitian}

Jenis penelitian ini adalah penelitian kuantitatif pada tingkatan explanatory yang bertujuan untuk menguji hipotesis adanya pengaruh mediasi kinerja proses internal terhadap hubungan strategi inovasi dengan kinerja keuangan. Penelitian ini dirancang sebagai causal studies (Cooper dan Emory, 1995).

Data dikumpulkan dengan media kuesioner. Unit analisis penelitian ini adalah unit bisnis. Responden penelitian adalah manajer unit bisnis entitas manufaktur di Jawa Timur. Penelitian ini merupakan penelitian perilaku yang menggunakan persepsi manajer unit bisnis sebagai pihak yang dianggap memiliki pengetahuan yang cukup holistik tentang variabel-variabel penelitian.

\section{Populasi dan Sampel}

Populasi penelitian ini adalah seluruh entitas manufaktur di Jawa Timur yang berjumlah 398 entitas. Untuk menghindari rendahnya respons terhadap kuesioner penelitian, maka kuesioner dikirim melalui fax dan email kepada seluruh populasi tersebut. Untuk meningkatkan response rate, maka dilakukan wawancara melalui telpon. Sampai batas waktu pengumpulan data, sebanyak 135 kuesioner dapat terisi atau response rate sebesar 34 persen.

\section{Klasifikasi Variabel}

Variabel-variabel dalam penelitian ini diklasifikasikan sebagai berikut: (1) Kinerja keuangan merupakan Variabel Dependen, (2) Strategi inovasi merupakan Variabel Independen, (3) Kinerja proses internal merupakan Variabel Mediasi.

\section{Definisi Operasional Variabel Kinerja keuangan}

Kinerja keuangandidefinisikan sebagai suatu konsekuensi dari suatu keputusan ekonomi yang diambil dari suatu tindakan ekonomi. Kinerja keuangan mengacu pada konsep Balanced Scorecard yang dikembangkan oleh Kaplan dan Norton (2001) yang 
menunjukkan adanya perencanaan, implementtasi serta evaluasi dari pelaksanaan strategi yang telah ditetapkan. Variabel kinerja keuangan ini meliputi 3 (tiga) indikator yaitu: pertumbuhan pendapatan, pengurangan atau penghematan biaya dan peningkatan penggunaan asset serta peningkatan nilai pelanggan.

\section{Strategi inovasi}

Strategi yang dimaksudkan dalam penelitian ini adalah strategi inovasi yang diterapkan secara berkelanjutan, yang didefinisikan sebagai cara yang digunakan entitas untuk bersaing dalam industrinya secara berkelanjutan. Variabel strategi inovasi dalam penelitian mengacu pada penelitian yang dilakukan oleh Terziovski (2002 dan 2010). Jenis strategi yang yang dipilih dalam penelitian adalah strategi inovasi integrated, yang merupakan gabungan antara strategi inovasi radical dan strategi inovasi incremental. Instrumen yang dikembangkan dalam penelitian ini menyangkut 2 (dua) aspek yaitu inovasi produk dan proses, dan teknologi informasi. Dengan menggunakan 5 point skala Likert, responden diberi pertanyaan tentang posisi entitas dibandingkan entitas lain dari dua aspek inovasi dan teknologi informasi.

\section{Kinerja Proses Internal}

Kinerja proses internal didefinisikan sebagai proses bisnis internal yang mengacu pada konsep Balanced Scorecard yang dikembangkan oleh dan Norton (2009) menjelaskan bagaimana proses dalam organisasi dilakukan untuk mendukung pemuasan kebutuhan pelanggan. Variabel Kinerja Proses Internal mencakup 4 (empat) indikator yaitu: operations management process, customer management process, innovation process dan regulatory dan social processes. Kinerja proses internal dalam penelitian ini, dikembangkan dari masing-masing sasaran strategis dengan menentukan KPI (key performance indicators). Kuesioner dalam penelitian ini terdapat 4 pertanyaan yaitu pertanyaan no. 38 sampai dengan no. 41 dengan pengukuran skala Likert 5 poin, angka 1 (sangat tidak setuju) sampai dengan angka 5 (sangat setuju).

\section{Pengembangan Hipotesis}

Inovasi dalam implementasi strategi memerlukan peran kinerja proses internal karena dengan adanya inovasi dalam implementasi strategi akan meningkatkan produktivitas entitas yang pada akhirnya berdampak pada kinerja keuangan.

Hipotesis dalam penelitian ini adalah:

$\mathrm{H}_{1}$ : Strategi inovasi berpengaruh terhadap kinerja keuangan secara langsung.

$\mathrm{H}_{2}$ : Strategi inovasi berpengaruh terhadap kinerja proses internal secara langsung.

$\mathrm{H}_{3}$ : Kinerja Proses internal berpengaruh kinerja keuangan secara langsung.

$\mathrm{H}_{4}$ : trategi inovasi berpengaruh terhadap kinerja keuangan yang dimediasi kinerja proses internal.

\section{Pengujian Hipotesis Mediasi}

Fokus dari penelitian ini adalah pengaruh mediasi kinerja proses internal terhadap hubungan strategi inovasi dengan kinerja keuangan. Analisis data penelitian ini menggunakan pendekatan Partial Least Square (PLS). PLS adalah model persamaan struktural (SEM) yang berbasis komponen atau varian (variance). Analisis structural equation modeling (SEM) dengan program WARP PLS versi 3.00 digunakan untuk menguji hipotesis.

Metode pemeriksaan pengaruh mediasi dilakukan dengan cara melakukan dua kali analisis, yaitu analisis dengan melibatkan variabel mediasi dan analisis tanpa melibatkan variabel mediasi. Analisis tanpa melibatkan variabel mediasi atau pengaruh langsung strategi inovasi berkelanjutan dengan kinerja keuangan menunjukkan bahwa strategi inovasi berkelanjutan berpengaruh terhadap kinerja keuangan dan secara statistik signifikan pada level 5\%.

Langkah selanjutnya adalah melakukan analisis yang melibatkan variabel mediasi. Pengujian pengaruh mediasi dilakukan dengan pendekatan perbedaan koefisien. 
Metode pemeriksaan variabel mediasi dengan pendekatan perbedaan koefisien dilakukan dengan langkah sebagai berikut: (a) memeriksa pengaruh variabel independen terhadap variabel dependen pada model tanpa melibatkan variabel mediasi, (b) memeriksa pengaruh langsung variabel independen terhadap variabel dependen pada model dengan melibatkan variabel mediasi, (c) memeriksa pengaruh variabel independen terhadap variabel mediasi, dan (d) memeriksa pengaruh variabel mediasi terhadap variabel dependen (Solimun, 2010; Hair et al., 2010, 2013; Kock, 2010, 2011, 2014).

\section{Pengembangan Model Berbasis Teori}

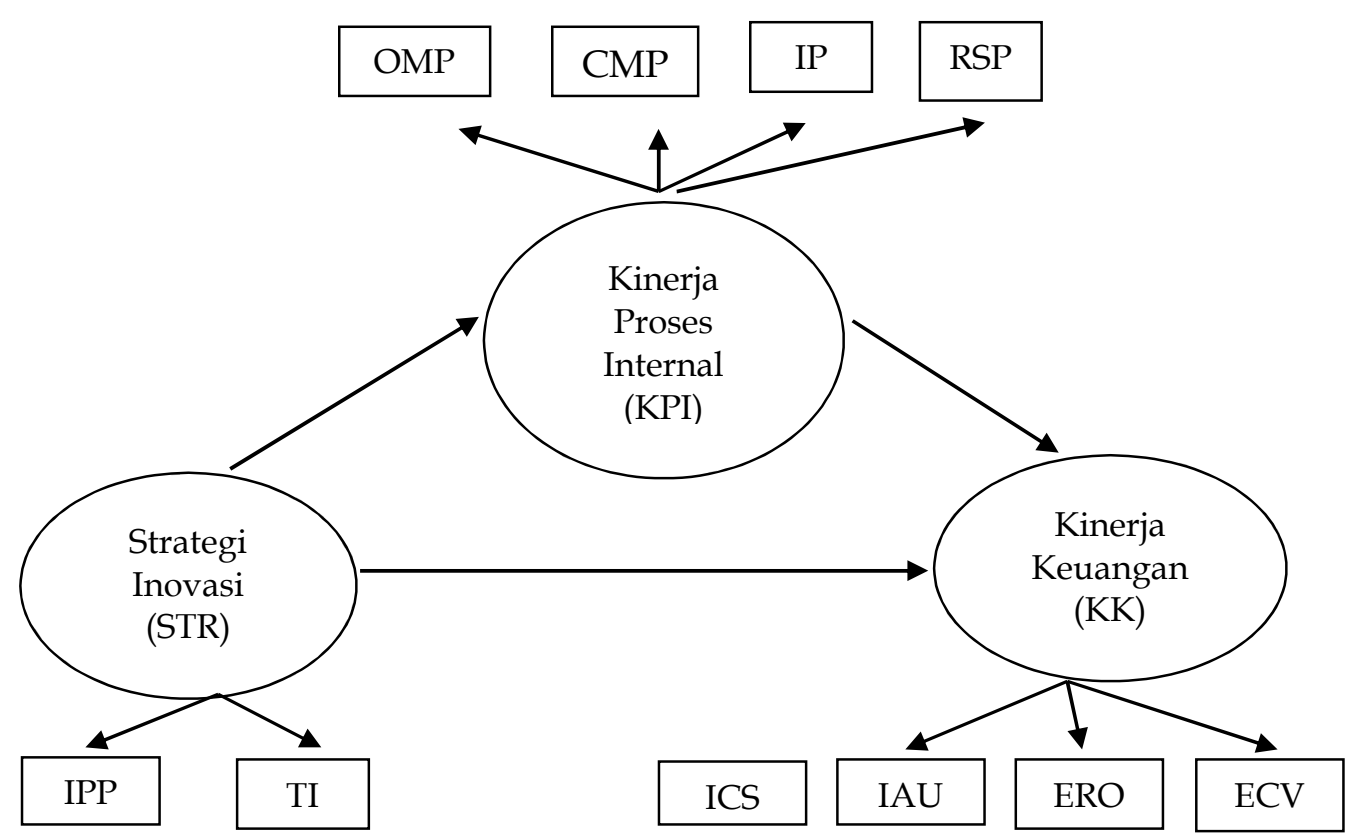

Gambar 2

Model berbasis teori

Keterangan:
STR = Strategi
IPP = Inovasi Produk dan proses
$\mathrm{TI}=$ Teknologi informasi

\author{
$\mathrm{KK}=$ Kinerja Keuangan \\ ICS = Improve cost structure \\ $I A U=$ Increase Asset Utilization \\ $E R O=$ Expand Revenue Opportunity \\ $E C V=$ Enhance Customer Value
}

\section{ANALISIS DAN PEMBAHASAN}

Fokus dari penelitian ini adalah menguji peran mediasi kinerja proses internal terhadap hubungan antara strategi inovasi dengan kinerja keuangan.

Uji statistik yang pertama dilakukan dengan menguji pengaruh langsung variabel Strategi terhadap variabel Kinerja Keuangan, yang kemudian dilakukan uji pengaruh tidak langsung yang melibatkan variabel mediasi.

\section{Uji Pengaruh Langsung}

Uji pengaruh langsung yang dimaksudkan adalah uji hubungan strategi inovasi dengan kinerja keuangan. Adapun langkah langkah uji pengaruh langsung adalah sebagai berikut: 


\section{Uji validitas}

Pada tabel 1 dapat dilihat bahwa, nilai loading dari indikator Strategi Inovasi (S3 dan S6) dan Kinerja Keuangan (kk1,kk2, kk3,kk4) lebih dari 0,70 dengan nilai p-value kurang dari 5\% (signifikan), hal ini berarti pengukuran konstruk Strategi Inovasi dan Kinerja Keuangan telah memenuhi syarat validitas konvergen. Validitas konvergen juga bisa dilihat dari nilai AVE. Nilai AVE dari variabel STR dan KK lebih dari 0,50 yang berarti pengukuran konstruk STR dan KK telah memenuhi syarat validitas konvergen.

\section{Uji Reliabilitas, Kolinearitas dan Ke- cocokan Model}

Tabel 2 menunjukkan hasil uji reliabilitas. Uji reliabilitas dapat dilihat dari Composite Reliability Coefficients dan Cronbach's Alpha Coefficients. Nilai Composite Reliability Coefficients dan Cronbach's Alpha Coefficients dari variabel STR dan KK lebih dari 0,70 yang berarti variabel STR dan KK adalah reliabel. Nilai AVE pada variabel STR dan KK kurang dari 3,3 maka dapat dikatakan bahwa model bebas dari masalah kolinearitas vertical, lateral dan common method bias. Nilai average path coefficient (APC) yang dihasilkan sebesar 0,730 dan signifikan kurang dari 5\%.

Nilai average $R$-Square (ARS) yang dihasilkan sebesar 0,533 dan signifikan kurang dari $5 \%$. Nilai average variance inflation factor (AVIF) sebesar 1 kurang dari 5. Dengan demikian, dapat disimpulkan bahwa goodness of fit model telah terpenuhi.

\section{Hasil Estimasi Koefisien Jalur dan Effect Size}

Pada tabel 3 menunjukkan bahwa koefisien jalur yang dihasilkan adalah positif yaitu sebesar 0,730 dengan p-value kurang dari 5\%. Hal ini berarti STR berpengaruh positif signifikan terhadap KK yaitu semakin baik STR maka KK semakin baik. Nilai Effect Size yang dihasilkan sebesar 0,533 lebih dari 0,35 menunjukkan bahwa STR memiliki pengaruh yang besar terhadap KK yang berarti STR punya peran yang sangat penting untuk meningkatkan KK.

Besarnya pengaruh STR terhadap KK dapat dilihat dari nilai $R$-Squared Coefficients yaitu sebesar 0,533 yang berarti besarnya pengaruh STR terhadap KK adalah sebesar $53,3 \%$. Adapun hasil dari uji pengaruh langsung pada Gambar 3.

\section{Uji Pengaruh Tidak Langsung}

Uji pengaruh tidak langsung yang dimaksudkan adalah uji hubungan strategi inovasi dengan kinerja keuangan melalui variabel mediasi kinerja proses internal. Langkah-langkah dari uji pengaruh tidak langsung adalah sebagai berikut:

Tabel 1

Nilai Uji Validitas

\begin{tabular}{lllll}
\hline \hline & STR & KK & SE & P value \\
s3 & $(0.920)$ & 0.079 & 0.084 & $<0.001$ \\
s6 & $(0.920)$ & -0.079 & 0.095 & $<0.001$ \\
kk1 & -0.235 & $(0.836)$ & 0.059 & $<0.001$ \\
kk2 & -0.232 & $(0.855)$ & 0.054 & $<0.001$ \\
kk3 & 0.118 & $(0.917)$ & 0.071 & $<0.001$ \\
kk4 & 0.321 & $(0.895)$ & 0.091 & $<0.001$ \\
& & & & \\
\hline STR & 0.847 & & & \\
KK & 0.768 & & &
\end{tabular}

Sumber : Hasil Pengolahan Data 
Tabel 2

Nilai Uji Reliabilitas, Kolinearitas dan Kecocokan Model

\begin{tabular}{ll}
\hline Composite Reliability Coefficients & Cronbach's Alpha Coefficients \\
STR 0.917 & STR 0.819 \\
KK 0.930 & KK 0.899 \\
\hline Uji Kolinearitas & Kecocokan Model \\
STR 2,042 & APC $=0.730, P<0.001$ \\
KK 2,042 & ARS $=0.533, \mathrm{P}<0.001$ \\
& AVIF $=1.000$, Good if $<5$ \\
\hline
\end{tabular}

Sumber : Hasil Pengolahan Data

Tabel 3

Hasil Estimasi Koefisien Jalur dan Effect Size

\begin{tabular}{|c|c|c|c|c|c|c|c|}
\hline \multicolumn{3}{|c|}{ Path coefficients } & \multicolumn{3}{|c|}{ P values } & \multicolumn{2}{|r|}{ Effect Size } \\
\hline & STR & KK & & STR & KK & STR & KK \\
\hline STI & & & STR & & & STR & \\
\hline KK & 0.730 & & KK & $<0.001$ & & KK & 0.533 \\
\hline
\end{tabular}

Sumber : Hasil Pengolahan Data

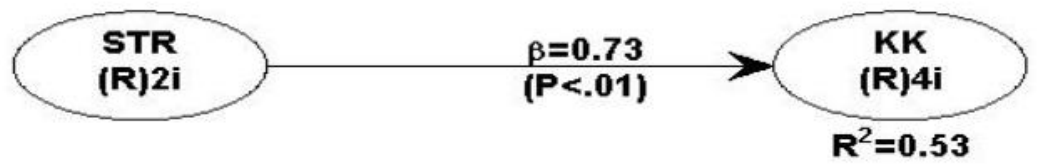

Gambar 3

Pengaruh Langsung Strategi Inovasi dengan Kinerja Keuangan

\section{Uji validitas}

Pada Tabel 4, menunjukkan bahwa Nilai loading dari indikator STR, KPI dan KK lebih dari 0,70 dengan nilai p-value kurang dari 5\% (signifikan), hal ini berarti pengukuran konstruk STR, KPI dan KK telah memenuhi syarat validitas konvergen. Validitas konvergen juga bisa dilihat dari nilai AVE. Nilai AVE dari variabel STR, KPI dan KK lebih dari 0,50 yang berarti pengukuran konstruk STR, KPI dan KK telah memenuhi syarat validitas konvergen.

\section{Uji Reliabilitas, Kolinearitas dan Ke- cocokan Model}

Tabel 5 menunjukkan bahwa Uji reliabilitas dapat dilihat dari Composite Reliability Coefficients dan Cronbach's Alpha Coefficients. Nilai Composite Reliability Coefficients dan Cronbach's Alpha Coefficients dari variabel
STR, KPI dan KK lebih dari 0,70 yang berarti variabel STR, KPI dan KK adalah reliabel. Nilai AVE pada variabel STR, KPI dan KK kurang dari 3,3 maka dapat dikatakan bahwa model bebas dari masalah kolinearitas vertical, lateral dan common method bias.

Nilai average path coefficient (APC) yang dihasilkan sebesar 0,556 dan signifikan kurang dari 5\%. Nilai average R-Square (ARS) yang dihasilkan sebesar 0,659 dan signifikan kurang dari $5 \%$. Nilai average variance inflation factor (AVIF) sebesar 2,545 kurang dari 5.

Dengan demikian, dapat disimpulkan bahwa goodness of fit model telah terpenuhi.

Hasil Estimasi Koefisien Jalur dan Effect Size

Pada Tabel 6 menunjukkan koefisien jalur yang dihasilkan adalah positif dengan p-value kurang dari 5\%. 
Tabel 4

Nilai Uji Validitas

\begin{tabular}{llllll}
\hline \hline & STR & KPI & KK & SE & P value \\
s3 & 0.920 & -0.023 & 0.092 & 0.085 & $<0.001$ \\
s6 & 0.920 & 0.023 & -0.092 & 0.095 & $<0.001$ \\
kpi1 & 0.233 & 0.837 & -0.052 & 0.063 & $<0.001$ \\
kpi2 & -0.280 & 0.844 & 0.034 & 0.062 & $<0.001$ \\
kpi3 & -0.183 & 0.897 & -0.120 & 0.056 & $<0.001$ \\
kpi4 & 0.240 & 0.855 & 0.143 & 0.062 & $<0.001$ \\
kk1 & -0.262 & 0.039 & 0.836 & 0.059 & $<0.001$ \\
kk2 & -0.217 & -0.012 & 0.855 & 0.054 & $<0.001$ \\
kk3 & 0.062 & 0.089 & 0.917 & 0.071 & $<0.001$ \\
kk4 & 0.389 & -0.116 & 0.895 & 0.091 & $<0.001$
\end{tabular}

Nilai AVE :

STR KPI KK

$\begin{array}{llll}0.847 & 0.737 & 0.768\end{array}$

Sumber : Hasil Pengolahan Data

Tabel 5

Nilai Uji Reliabilitas, Kolinearitas dan Kecocokan Model

\begin{tabular}{llllll}
\hline \multicolumn{2}{l}{ Composite Reliability Coefficients } & \multicolumn{3}{c}{ Cronbach's Alpha Coefficients } \\
STR & KPI & KK & STR & KPI & KK \\
0.917 & 0.918 & 0.930 & 0.819 & 0.881 & 0.899
\end{tabular}

\section{Uji Kolinearitas}

STR KPI KK

$2.846 \quad 3.260 \quad 2.568$

\section{Kecocokan Model}

$\mathrm{APC}=0.556, \mathrm{P}<0.001$

ARS $=0.659, \mathrm{P}<0.001$

$\mathrm{AVIF}=2.545$, Good if $<5$

\section{Sumber : Hasil Pengolahan Data}

Hal ini berarti STR berpengaruh positif signifikan terhadap KPI, STR berpengaruh positif signifikan terhadap KK dan KPI berpengaruh positif signifikan terhadap KK. Nilai Effect Size antara variabel STR dengan KPI sebesar 0,692 (besar), menunjukkan bahwa STR memiliki pengaruh yang besar terhadap KPI. Nilai Effect Size antara variabel STR dengan KK sebesar 0,257 (medium), menunjukkan bahwa STR me miliki pengaruh yang medium terhadap KK. Nilai Effect Size antara variabel KPI dengan KK sebesar 0,368 (besar), menunjukkan bahwa KPI memiliki pengaruh yang besar terhadap KPI. Variasi KK dapat dijelaskan oleh variasi
STR dan KPI sebesar $62,6 \%$ sedangkan variasi KPI dapat dijelaskan oleh variasi STR sebesar $69,2 \%$.

\section{Indirect Effect}

Tabel 7 menunjukkan hasil pengaruh mediasi kinerja proses internal atas hubungan strategi inovasi dengan Kinerja keuangan. Hasil estimasi menunjukkan bahwa pengaruh STR terhadap KK secara tidak langsung dan melalui KPI adalah sebesar 40,3\% dan signifikan dengan $p$ value kurang dari $5 \%$. Adapun uji pengaruh tidak langsung dapat dilihat pada Gambar 4 dibawah ini. 
Tabel 6

Hasil Estimasi Koefisien Jalur dan Effect Size

\begin{tabular}{|c|c|c|c|c|c|c|c|c|c|}
\hline \multicolumn{4}{|c|}{ Path coefficients } & \multicolumn{3}{|c|}{ P values } & \multicolumn{3}{|c|}{ Effect Sizedan R-Squared } \\
\hline & STR & KPI & KK & & STR & KPI & STR & KPI & KK \\
\hline STR & & & & STR & & & STR & & \\
\hline KPI & 0.832 & & & KPI & $<0.001$ & & KPI & 0.692 & \\
\hline KK & 0.352 & 0.485 & & KK & 0.011 & $<0.001$ & KK & 0.257 & 0.368 \\
\hline
\end{tabular}

Sumber : Hasil Pengolahan Data

Tabel 7

Hasil pengaruh mediasi kinerja proses internal atas hubungan strategi inovasi dengan Kinerja keuangan

\begin{tabular}{|c|c|c|c|c|c|c|c|}
\hline & Indirect effects & & P values & & & & \\
\hline & $\begin{array}{lll}\text { STR } & \text { KPI } & \text { KK }\end{array}$ & & STR KPI & KK & STR & KPI & KK \\
\hline STR & & STR & & & & 0.692 & 0.626 \\
\hline KPI & & KPI & & & & & \\
\hline KK & 0.403 & KK & $<0.001$ & & & & \\
\hline
\end{tabular}

Sumber : Hasil Pengolahan Data

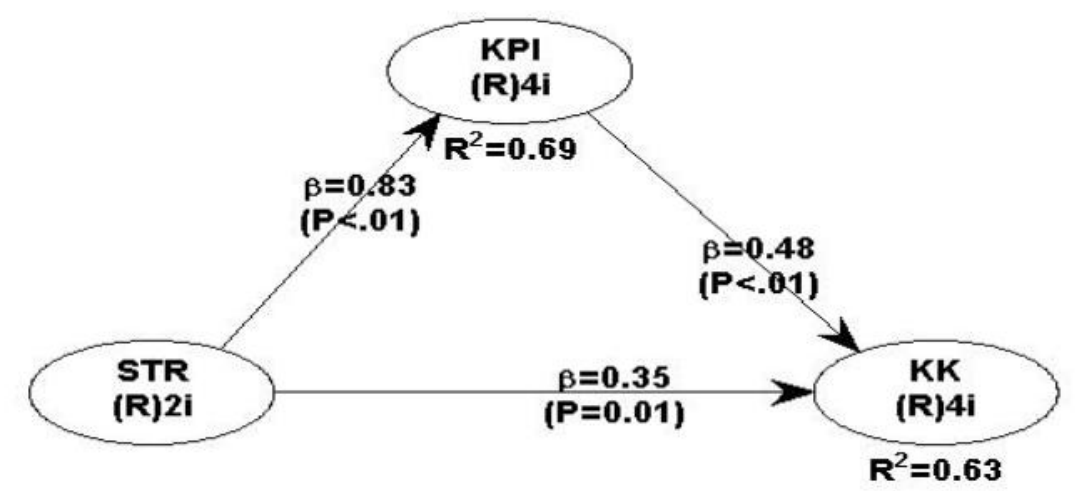

Gambar 4

Pengaruh tidak Langsung atas Strategi Inovasi dengan Kinerja Keuangan yang dimediasi kinerja proses internal

\section{Pembahasan}

Hipotesis dalam studi ini adalah strategi inovasi berpengaruh terhadap kinerja keuangan yang dimediasi kinerja proses internal. Kinerja proses internal memediasi secara parsial (partially mediating) atas hubungan antara strategi inovasi berkelanjutan (STR) dengan kinerja keuangan (KK). Inovasi produk dan inovasi proses serta implementasi teknologi sangat penting dalam strategi inovasi. Implementasi strategi inovasi berpengaruh pada kinerja proses internal yang meliputi Operations Management process,
Customer Management process, Innovation process, dan Regulatory dan Social processes.

Dalam penelitian ini, perusahaan-perusahaan manufaktur di Jawa Timur selalu meningkatkan efiensi dalam proses manajemen operasionalnya, dan dalam proses operasional perusahaan selalu berorientasi kepelanggan dengan melakukan inovasi produk dan proses. Perusahaan-perusahaan manufaktur di Jawa Timur juga sangat memperhatikan regulasi (aturan) yang berlaku dan selalu melakukan proses sosial untuk kepentingan para stakeholders seperti 
yang sudah dijelaskan pada pembahasan sebelumnya.

Hal tersebut diatas didukung oleh hasil penelitian dari Anatan dan Ellitan (2005), Jones, (2004) dan Terziovski (2002). Inovasi diartikan sebagai proses di dalam organisasi untuk memanfaatkan ketrampilan dan sumber daya untuk mengembangkan produk dan atau jasa baru atau untuk membangun sistem produksi dan operasional baru sehingga perusahaan mampu menjawab kebutuhan pelanggan (Jones, 2004). Terziovski (2002) dalam penelitiannya memberikan bukti bahwa inovasi memberikan pengaruh terhadap indikator kinerja proses internal, misalnya produktivitas perusahaan.

Strategi inovasi berkelanjutan berdampak pada kinerja keuangan bila terdapat kinerja proses internal yang baik, oleh karena itu, kinerja proses internal memedia sehubungan antara strartegi inovasi berkelanjutan (STR) dengan kinerja keuangan (KK), walaupun secara parsial. Hal ini menunjukkan bukan hanya kinerja proses internal yang memediasi hubungan antara strartegi inovasi berkelanjutan (STR) dengan kinerja keuangan (KK) namun masih terdapat variabel-variabel lain.

\section{SIMPULAN DAN SARAN}

Hasil penelitian menunjukkan bahwa, (1) strategi inovasi berpengaruh terhadap kinerja keuangan, (2) strategi inovasi berpengaruh terhadap Kinerja Proses Internal, (3) Kinerja Proses Internal berpengaruh terhadap kinerja keuangan, (4) Strategi inovasi berpengaruh terhadap kinerja keuangan melalui kinerja proses internal.

Fokus dari penelitian ini adalah pengaruh mediasi kinerja proses internal terhadap hubungan strategi inovasi dengan kinerja keuangan, oleh karena itu secara keseluruhan, hasil penelitian ini menunjukkan bahwa Strategi inovasi berpengaruh terhadap kinerja keuangan melalui kinerja proses internal. Peran kinerja proses internal menjadi penting atas hubungan strategi inovasi dengan kinerja pelanggan. Hal ini men- dukung RBT yang menyatakan faktor internal (yang dalam penelitian ini adalah kinerja proses internal) menjadi hal yang penting atas hubungan strategi inovasi dengan kinerja keuangan. Penggunaan teori kontijensi menjadi hal yang penting untuk menutup kesenjangan yang ada dalam RBT.

Terdapat beberapa keterbatasan dalam penelitian ini antara lain: (1) penelitian ini tidak mempertimbangkan siklus hidup bisnis, (2) peneliti tidak menganalisis variabel kinerja proses internal namun dalam penelitian ini, kinerja proses internal adalah gabungan antara Operations Management process, Customer Management process, Innovation process, Regulatory dan Social processes (3) sampel penelitian ini berasal dari entitas manufaktur saja sehingga temuan penelitian ini tidak dapat digeneralisasi ke industri lain.

Adapun saran untuk penelitian mendatang berkaitan dengan penelitian mendatang adalah: (1) mempertimbangkan siklus hidup bisnis, (2) menganalisis elemen dari kinerja proses internal, dan (3) memperluas sampel penelitian.

\section{DAFTAR PUSTAKA}

Anatan, T. L. dan L. Ellitan. 2005. Strategi Inovasi dan Kinerja Operasional Perusahaan: Sebuah Review Aplikasi Intellectual Capital Management Dalam Era Baru Manufaktur. Prosiding Seminar Nasional PESAT Jakarta: 217-228.

Banker, R. D., H. Chang, dan M. J. Pizzini. 2004. The Balanced Scorecard: Judgmental Effects of Performance Measures Linked to Strategy. The Accounting Review 79(1): 1-23.

Barney, J., M. Wright, dan D. J. Ketchen. 2001. The Resource-Based View of The Firm: Ten Years After 1991. Journal of Management 27(6): 625-641.

Bhargava, M., C. Dubelaar, dan S. Ramaswami. 1994. Reconciling Diverse Measures of Performance: a Conceptual Framework and Test of a Methodology. Journal of Business Research 31(2): 235246. 
Bisbe, J. dan D. Otley. 2004. The Effects of The Interactive Use of Management Control Systems on Product Innovation. Accounting, Organizations and Society 29(8): 709-737.

Bontis, N., M. M. Crossan, dan J. Hulland. 2002. Managing an Organizational Learning System by Aligning Stocks And Flows. Journal of management studies 39(4): 437-469.

Brahmana, S. S. 2007. Resources-Based View: The Effect of Product Innovation on Market Orientation and Performance Relationship. DeReMa Jurnal Manajemen 2: 94-110.

Burney, L. L. dan N. J. Swanson. 2010. The Relationship Between Balanced Scorecard Characteristics And Managers' Job Satisfaction. Journal of Managerial Issues 22(2): 166-181.

Cadez, S. dan C. Guilding. 2008. An Exploratory Investigation of an Integrated Contingency Model of Strategic Management Accounting. Accounting, Organizations and Society 33(7): 836-863.

Cardinaels, E. dan P. M. Van Veen-Dirks. 2010. Financial Versus Non-Financial Information: The Impact of Information Organization and Presentation in a Balanced Scorecard. Accounting, Organizations and Society 35(6): 565-578.

Cooper, D. R. and C. W. Emory. 1995. Business Research Methods. Irwin Inc. Chicago.

Dibrell, C. C., P. S. Davis, dan J. B. L. Craig. 2008. Fueling Innovation through Information Technology in SMEs. Journal of Small Business Management 46(2): 203218.

Disperindag Propinsi Jawa Timur. 2016. Data Pertumbuhan Industri di Wilayah Jawa Timur.

Evangelista, R., T. Sandven, G. Sirilli, dan K. Smith. 1998. Measuring Innovation in European Industry. International Journal of the Economics of Business 5(3): 311-333.

Hair, J. F. dan R. E. Anderson. 2010. Multivariate Data Analysis. Fifth Edition. Prentice Hall. New Jersey.
Hair, J. F. dan R. E. Anderson. 2013. Multivariate Data Analysis. Fifth Edition. Prentice Hall. New Jersey.

Hambrick, D. C. 1981. Environment, Strategy, dan Power Within Top Management Teams. Administrative Science Quarterly 26(2): 253-275.

Hamel, G. 1999. Bringing Silicon Valley Inside. Harvard Business Review 77(5): 7084.

Hitt, M. A., R. D. Ireland, S. M. Camp, dan D. L. Sexton. 2001. Strategic Entrepreneurship: Entrepreneurial Strategies for Wealth Creation. Strategic Management Journal 22(6-7): 479-491.

Igartua, J. I., J. A. Garrigos, dan J. L. HervasOliver. 2010. How Innovation Management Techniques Support an Open Innovation Strategy. Research Technology Management 53(3): 41-52.

Jones G.R. 2004. Organizational Theory, Design, and Change. Prentice Hall.

Kaplan, R. S. dan D. P. Norton. 2001. The Strategy-Focused Organization: How Balanced Scorecard Companies Thrive in the New Business Environment. Harvard Business School Publishing Corporation. United States of America.

Kaplan, R. S. dan D. P. Norton. 2001. Transforming the Balanced Scorecard from Performance Measurement to Strategic Management: Part II. Accounting Horizons 15(2): 147-160.

Kuratko, D. F., R. D. Ireland, J. G. Covin, dan J. S. Hornsby. 2005. A Model of MiddleLevel Managers' Entrepreneurial Behavior. Entrepreneurship Theory and Practice 29(6): 699-716.

Lendel, V. dan M. Varmus. 2011. Creation and Implementation of The Innovation Strategy in The Enterprise. Economics and Management 16: 819-826.

Lopez-Nicolas, C. dan A. L. Merono-Cerdan. 2011. Strategic Knowledge Management, Innovation and Performance. International Journal of Information Management 31(6): 502-509.

Kock, N. 2010. Using WarpPLS in Ecollaboration Studies: An Overview of 
Five Main Analysis Steps. International Journal of e-Collaboration 6(4): 1-11.

Kock, N. 2011. Using WarpPLS in eCollaboration Studies: Mediating Effects, Control and Second Order Variables, and Algorithm Choices. International Journal of e-Collaboration 7(3): 1-13.

Kock, N. 2014. Advanced Mediating Effects Tests, Multi-group Analyses, and Measurement Model Assessments in PLS-based SEM. International Journal of eCollaboration 10(1): 1-13.

Oke, A., F. O. Walumbwa, dan A. Myers. 2012. Innovation Strategy, Human Resource Policy, and Firms' Revenue Growth: The Roles of Environmental Uncertainty and Innovation Performance. Decision Sciences 43(2): 273-302.

Otley, D. T. 1980. The Contingency Theory of Management Accounting: Achievement and Prognosis. Accounting, Organizations and Society 5(4): 413-428.

Porter, M. E. 2008. Competitive Advantage: Creating and Sustaining Superior Performance. simonandschuster.com.

Riyanto, B. 1999. Identifikasi Isu Penelitian Akuntansi Manajemen: Pendekatan Kontinjensi. Media Akuntansi.

Sanchez, A., A. Lago, X. Ferras, dan J. Ribera. 2011. Innovation Management Practices, Strategic Adaptation, and Business Results: Evidence from the Electronics Industry. Journal of Technology Management $\mathcal{E}$ Innovation 6(2): 14-38.
Scheer, A. W. 2006. Corporate Performance Management, ARIS in Practice. Springer. Berlin.

Solimun, 2010. Analisis Multivariat Pemodelan Struktural Metode Partial Least SquarePLS. Penerbit CV. Citra. Malang.

Teece, D. J., G. Pisano, dan A. Shuen. 1997. Dynamic Capabilities and Strategic Management. Strategic Management Journal 18(7): 509-533.

Terziovski, M. 2002. Achieving Performance Excellence Through an Integrated Strategy of Radical Innovation and Continuous Improvement. Measuring Business Excellence 6(2): 5-14.

Terziovski, M. 2009. Energizing Management through Innovation and Entrepreneurship: European Research and Practice (Routledge Studies in Innovation, Organization and Technology). Routledge. London.

Terziovski, M. 2010. Innovation Practice and its Performance Implications in Small and Medium Enterprises (SMEs) in The Manufacturing Sector: A Resourcebased View. Strategic Management Journal 31: 892-902.

Venkatraman, N. dan V. Ramanujam. 1986. Measurement of Business Performance in Strategy Research: a Comparison of Approaches. Academy of Management Review 11(4): 801-814.

Ulusoy, G., A. Özgür, T. Bilgiç, A. R. Kaylan, dan E. Payzin. 2001. A Study on Technology Management Process: The Parts and Components Suppliers in The Turkish Automotive Industry. Technology Management 5(4): 245-260. 